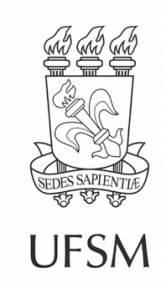

\title{
Artigos
}

\section{Soil microbiological activity under different vegetation coverages in the Cerrado biome of Tocantins state}

\author{
Atividade microbiológica do solo sob diferentes coberturas vegetais no \\ Cerrado tocantinense
}

\author{
Josué Luiz Marinho Junior ${ }^{\oplus}$, Victor Casimiro Piscoya" ${ }^{\oplus}$, \\ Moacyr Cunha Filho" ${ }^{\oplus}$, Milton Marques Fernandes ${ }^{\prime \prime \prime} \odot$, \\ Alceu Pedrotti"' ${ }^{\bullet}$, Thaisa Oliveira Folha Piscoyalv ${ }^{\bullet}$, \\ Raimundo Rodrigues Gomes Filho"' ${ }^{\oplus}$, Fabricio Souza Campos ${ }^{\oplus}$, \\ Francisco Sandro Rodrigues Holanda"' ${ }^{\circ}$, Jamilie Brito de Castro ${ }^{\oplus}$, \\ Jorge Luis Piscoya Roncalv ${ }^{\bullet}$, Renisson Neponuceno de Araújo Filho ${ }^{\oplus}$ \\ 'Universidade Federal do Tocantins, Gurupi, TO, Brazil \\ "Universidade Federal Rural de Pernambuco, Recife, PE, Brazil \\ '"Universidade Federal de Sergipe, São Cristovão, SE, Brazil \\ 'vSuperintendência do Desenvolvimento do Nordeste, Recife, PE, Brazil \\ vUniversidad Nacional de Trujillo, Trujillo, Peru
}

\begin{abstract}
The microbial activity is very sensitive to changes in soil cover, making it an important indicator of soil quality. The study aimed to assess changes in soil microbiological activities under different vegetation coverings in the Cerrado biome of Tocantins state. The work was developed in areas of Eucalyptus sp., Pasture, agriculture and Cerrado sensu stricto in the experimental farm of the Federal University of Tocantins. The soil samples were collected in trenches of $70 \times 70 \mathrm{~cm}$ at depths $0-10$ and 10-20 cm, with six replications. The variables evaluated were: concentration and stock in the microbial biomass carbon, basal soil respiration, metabolic quotient and microbial quotient. The statistical analysis was performed using the normality test, analysis of variance and comparison of means by the Tukey test at 5\% significance. The area with Eucalyptus sp. at 11 years of age, he had a stable soil microbiological activity, showing stocks in microbial biomass carbon 57.32\% higher than that native forest vegetation, $84.29 \%$ that pasture and $290.91 \%$ that agriculture. The soil microbiological activities are affected by the variation of the soil vegetation cover, being efficient as an indicator of soil quality.
\end{abstract}

Keywords: Bioindicators; Soil respiration; Metabolic quotient; Microbial biomass carbon 


\section{RESUMO}

A atividade microbiana se mostra bastante sensível a mudanças da cobertura, tornando-se um importante indicador de qualidade do solo. O estudo teve como objetivo avaliar as alterações nas atividades microbiológicas do solo sob as diferentes coberturas vegetais no cerrado do Tocantins. 0 trabalho foi desenvolvido em áreas de Eucalyptus sp., pastagem, agricultura e cerrado sensu stricto na fazenda experimental da Universidade Federal do Tocantins. As amostras de solo foram coletadas em trincheiras de $70 \times 70 \mathrm{~cm}$ nas profundidades 0-10 e 10-20 cm, com seis repetições. As variáveis avaliadas foram: concentração e estoque de carbono na biomassa microbiana, respiração basal do solo, quociente metabólico e quociente microbiano. A análise estatística foi realizada por meio do teste de normalidade, análise de variância e comparação das médias pelo teste Tukey a 5\% de significância. A área com Eucalyptus sp. com 11 anos apresentou uma atividade microbiológica do solo estável, apresentando estoques de carbono na biomassa microbiana superiores em 57,32 \% aos da vegetação de mata nativa, $84,29 \%$ ao da pastagem e $290,91 \%$ ao da agricultura. As atividades microbiológicas do solo são afetadas pela variação da cobertura vegetal do solo, sendo eficiente como indicador de qualidade do solo.

Palavras-chave: Bioindicadores; Respiração do solo; Quociente metabólico; Carbono da biomassa microbiana

\section{INTRODUCTION}

In ideal conditions, the topsoil shows a great capacity to store carbon, this capacity being closely related to the soil microbial activity. In Brazil, about $50 \%$ of the soil organic carbon (SOC) is stored in the first $30 \mathrm{~cm}$ of the soil, and the global average of SOC accumulation for the topsoil is around 35\% (BATJES, 2016).

The microbial activity, as it distinguishes between the types of land use, becomes an indicator of quality, being directly related to SOC concentrations (MOGHIMIAN et al., 2019). The biggest changes in soil microbial biomass (SMB) are concentrated in the superficial layers. The soil organic matter (SOM) also plays an important role in the soil microbiota, with the presence of SOM regulating soil microbial activity and directly related to the mobilization of nutrients such as nitrogen and phosphorus and, consequently, the soil fertility (MUSHINSKI; GENTRY; BOUTTON, 2019).

Thus, it emphasizes the importance of knowing the quality indicators of the activity of soil microorganisms (MOGHIMIAN et al., 2019). BMS and basal soil respiration (BSR) when evaluated in sets are good microbial indicators (MOSCATELLI et al., 2007). The ratio between $\mathrm{BSR}$ and $\mathrm{SMB}$, per unit of time results in the metabolic quotient $\left(\mathrm{qCO}_{2}\right)$ which is 
the amount of $\mathrm{CO}_{2}$ released by SMB as a function of time, being considered the specific respiration of soil microorganisms. And the microbial quotient (qMIC) is the relationship between microbial biomass carbon (MBC) and SOC (MOSCATELLI et al., 2007). These indicators highlight the importance of the microbial activity in the global carbon cycle and in soil quality control, in different forest ecosystems (MOGHIMIAN et al., 2019).

The knowledge of changes in vegetation cover in soil microbial activity is of great importance for the control of $\mathrm{CO}_{2}$ emissions (SOLEIMANI et al., 2019). In the view of the above, the objective of this study was to evaluate changes in soil microbiological activities under different vegetation coverings in the Cerrado of Tocantins.

\section{MATERIAL AND METHODS}

\subsection{Study area}

The work was conducted at the experimental farm of "Universidade Federal do Tocantins", municipality of Gurupi, state of Tocantins, in the geographical coordinates $11^{\circ} 46^{\prime} 25^{\prime \prime} \mathrm{S}$ and $49^{\circ} 02^{\prime} 54^{\prime \prime} \mathrm{W}$ (Figure 1).

Figure 1 - Location of experimental areas with native forest, Eucalyptus sp., pasture and agriculture in Gurupi, Tocantins state

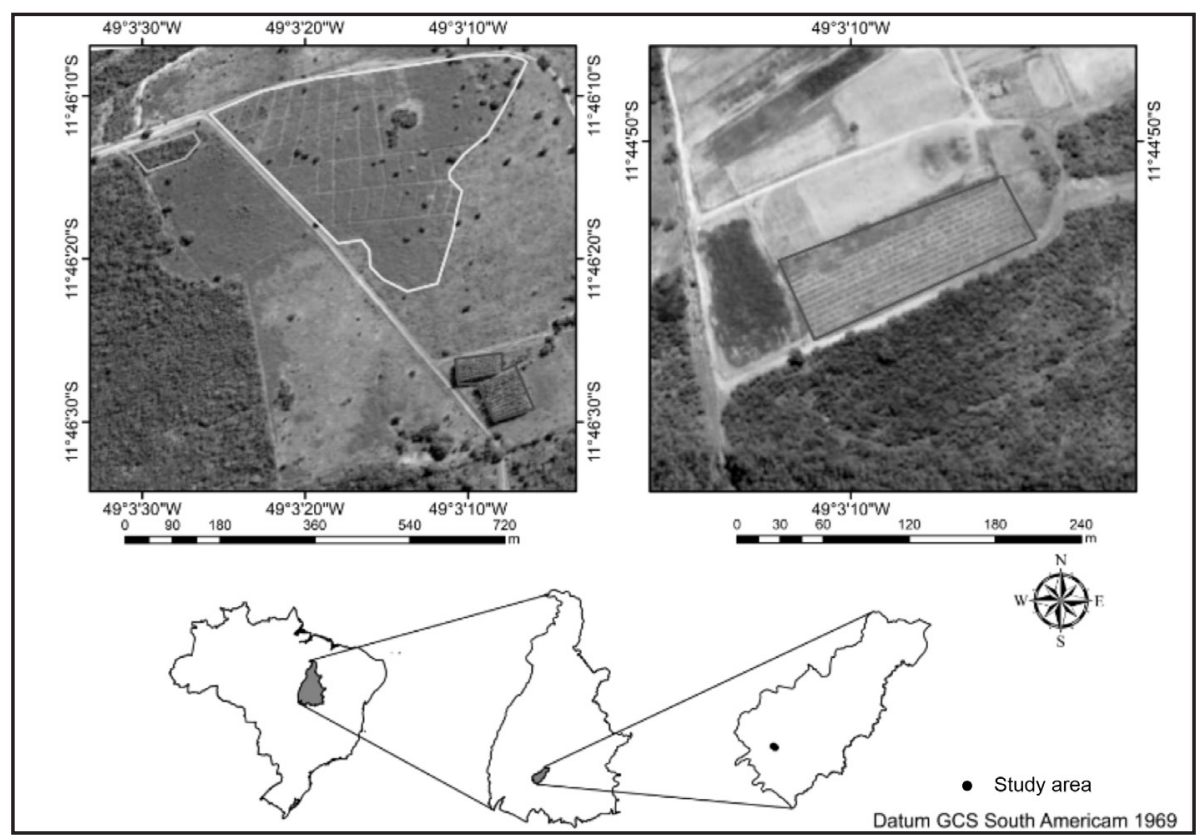

Source: Authors (2020) 
The climate of the region according to Thornthwaite is of the B1 wA'a' type, having two well-defined seasons, with about six months of drought, comprising the winter period and six months of rain that correspond to the summer. The average annual temperature is $27^{\circ} \mathrm{C}$ and the average annual precipitation is $1,500 \mathrm{~mm}$ (TOCANTINS, 2017). The soil was classified as a petric Plinthosol (SANTOS et al., 2018). The studied areas were with Eucalyptus sp., Pasture, Agriculture and Native Forest as a witness. Each area had the following characteristics:

- Native forest: the area covers 22.82 ha, aged over 60 years, without recent burns or cuts of vegetation in the area. The ground cover had a large amount of litter and the vegetation was characterized by five species of higher importance values Myrcia splendens (Sw.) DC. (13.04\%), Qualea multiflora Mart. (9.87\%), Protium heptaphyllum (Aubl.) Marchand (7.53\%), Magonia pubescens A. St.-Hil. (5.35\%), Qualea grandiflora Mart. (5.02\%) (BENDITO et al., 2018).

- Eucalyptus sp.: the area is 0.65 ha and 11 years old and its implementation was carried out through deforestation with a bulldozer and front shovel, followed by plowing and harrowing. Seedlings $25 \mathrm{~cm}$ high were planted in pits in the dimensions of $0.4 \times 0.4 \times 0.4 \mathrm{~m}$ with the help of excavators and $3 \times 2 \mathrm{~m}$ spacing. Then, fertilization was carried out with $100 \mathrm{~g}$ of simple superphosphate at the bottom of the pit and partially buried, then $150 \mathrm{~g}_{\text {per }}$ pit-1 $^{-1}$ of NPK were added in formulation 5-25-15. After its implantation, the thinning was not carried out on the trees and the ground cover was made up of leaves and small branches of Eucalyptus sp.. The manual weeding is also carried out in the area to control weeds.

- Pasture: the area has 11.25 ha with native pasture and predominance of Andropogon grass over 40 years old, without animals present. Other species of poaceas have been recorded such as: Spalum notatum, Eragrostis bahiensis, Axonopus affinis, Bothriochloa laguroides, Schizachyrium microstachyum, Paspalum dilatatum, Sporobolus indicus, Rhynchospora sp., Andropogon ternatus, Panpalumis sp. 
- Agriculture: The area has 0.95 ha and the soil preparation was done using a leveling harrow and disc plow, and the weeds were controlled by manual weeding associated with the use of full-action herbicides such as Glyphosate, operations adopted when necessary. Over the past 6 years the corn crop was grown in the area, planted annually in the period between February and March at an average spacing of $0.2 \times 0.8 \mathrm{~m}$. For sowing, a manual planter-fertilizer was used, which enabled the basic fertilization. The nutrients applied at the time of corn sowing consisted of nitrogen in the form of ammonium sulphate $(45 \% \mathrm{~N})$, phosphorus in the form of triple superphosphate $\left(42 \% \mathrm{P}_{2} \mathrm{O}_{5}\right)$ and potassium in the form of potassium chloride (58\% of $\mathrm{K}_{2} \mathrm{O}$ ), corresponding to 120,170 and $140 \mathrm{~kg} \mathrm{ha}^{-1}$, respectively of $\mathrm{N}, \mathrm{P}$ and $\mathrm{K}$, with $\mathrm{N}$ applied $50 \%$ at 25 days and $50 \%$ at 45 days after sowing. At other times of the year, no cultivation of any kind was carried out in the area, with corn stubble being the only soil covering.

\subsection{Soil samples}

Six trenches selected at random equidistant from each other around $30 \mathrm{~m}$, were opened with dimensions $70 \times 70 \mathrm{~cm}$ and depth of $20 \mathrm{~cm}$ in each area. The soil samples were collected at depths 0-10 and 10-20 cm, and the deformed samples were dried in air at room temperature and passed through a $2 \mathrm{~mm}$ sieve to perform physical analysis. The non-deformed samples were collected and submitted to soil density analysis.

\subsection{Physical analysis}

The soil density was determined by the volumetric cylinder method and granulometric analysis was performed using the pipette method (DONAGEMMA et al., 2017). 


\subsection{Microbiological analysis}

For the microbiological analysis, soil samples were subjected to basal soil respiration (BSR) (ISERMEYER, 1952), microbial biomass carbon (MBC) by the irradiation extraction method using a microwave oven (frequency of $900 \mathrm{~W}$ and $2450 \mathrm{MHz}$ ), according to the method described by Islam and Weil (1998), and the C extracts were determined from irradiated and non-irradiated samples using colorimetry method (BARTLETT; ROSS, 1988), metabolic quotient $\left(\mathrm{qCO}_{2}\right)$, obtained by dividing the baseline respiration per unit of MBC (ANDERSON; DOMSCH, 1989), and microbial quotient (qMIC), obtained by dividing MBC by soil carbon. In the determination of carbon from soil microbial biomass, the irradiation extraction method was used, which analyzes the extractable microbial biomass in aqueous $\mathrm{K}_{2} \mathrm{SO}_{4}$ solution $0.5 \mathrm{~mol} \mathrm{L-1}$.

The $\mathrm{C}$ concentrations were converted into carbon stock in soil microbial biomass (S-SMB) in $\mathrm{Mg} \mathrm{ha}^{-1}$ for each depth sampled as follows, Equation (1):

$$
M B C \text { Stock }=\left(M B C \times S_{D} \times V S D\right) \times 1000
$$

Where: MBC Stock is the stock in microbial biomass carbon in the soil layer, in ( $\left.\mathrm{Mg} \mathrm{ha}^{-1}\right)$; $\mathrm{MBC}$ is the concentration in the microbial biomass carbon in the soil sample, in ( $\left.\mathrm{kg} \mathrm{Mg}^{-1}\right)$; $\mathrm{S}_{\mathrm{D}}$ is the soil density in the layer, in $\left(\mathrm{Mg} \mathrm{m}^{-3}\right)$ and the VSD is the volume sampled depth, in $\left(\mathrm{m}^{3}\right)$. The total stock of $\mathrm{C}$ in the microbial biomass at a depth of 0 to $20 \mathrm{~cm}$ was calculated by adding the values obtained in each sampled layer.

\subsection{Statistical analysis}

The parameters evaluated concentrations and stocks of $\mathrm{C}$ in the microbial biomass were subjected to normality tests Shapiro and Wilk, then performed the analysis of variance to evaluate the differences between the uses of the soil in the depths. The comparison of means was performed by the Tukey test at $5 \%$ significance and using the statistical software SISVAR (FERREIRA, 2011). 


\section{RESULTS AND DISCUSSION}

In general, the granulometric composition of the soil showed a predominance of medium texture, being classified as sandy-clay-loam in all soil depths of the analyzed areas (Table 1).

Table 1 - Physical characteristics of Cerrado soil in different vegetation coverings in Gurupi, Tocantins state, Brasil

\begin{tabular}{|c|c|c|c|c|c|c|}
\hline \multirow[t]{2}{*}{ Vegetal Cover } & $\begin{array}{c}\text { Coarse } \\
\text { Sand }\end{array}$ & Fine Sand & Silt & Clay & $\begin{array}{c}\text { Soil } \\
\text { Density }\end{array}$ & \multirow[t]{2}{*}{ Texture } \\
\hline & \multicolumn{4}{|c|}{$\%$} & $\mathrm{~g} \mathrm{~cm}^{-3}$ & \\
\hline \multicolumn{7}{|c|}{ Depth $0-10 \mathrm{~cm}$} \\
\hline Native Forest & $57.50 \pm 2.85$ & $6.33 \pm 1.89$ & $8.44 \pm 1.32$ & $27.73 \pm 3.01$ & $1.45 \pm 0.06$ & Sandy-clay-loam \\
\hline Eucalyptus sp. & $54.85 \pm 3.12$ & $9.98 \pm 2.99$ & $9.19 \pm 1.23$ & $25.98 \pm 2.38$ & $1.40 \pm 0.05$ & Sandy-clay-loam \\
\hline Pasture & $55.59 \pm 1.79$ & $13.44 \pm 1.63$ & $6.64 \pm 0.57$ & $24.33 \pm 1.21$ & $1.55 \pm 0.08$ & Sandy-clay-loam \\
\hline Agriculture & $56.71 \pm 1.59$ & $9.41 \pm 3.71$ & $7.86 \pm 0.80$ & $26.02 \pm 3.32$ & $1.37 \pm 0.06$ & Sandy-clay-loam \\
\hline \multicolumn{7}{|c|}{ Depth $10-20 \mathrm{~cm}$} \\
\hline Native Forest & $59.96 \pm 2.03$ & $4.71 \pm 2.12$ & $8.51 \pm 2.33$ & $26.82 \pm 2.24$ & $1.51 \pm 0.05$ & Sandy-clay-loam \\
\hline Eucalyptus sp. & $56.04 \pm 2.24$ & $9.09 \pm 1.90$ & $6.85 \pm 2.17$ & $28.02 \pm 1.91$ & $1.53 \pm 0.07$ & Sandy-clay-loam \\
\hline Pasture & $57.84 \pm 1.32$ & $10.55 \pm 1.84$ & $7.26 \pm 1.75$ & $24.35 \pm 1.76$ & $1.59 \pm 0.05$ & Sandy-clay-loam \\
\hline Agriculture & $57.84 \pm 1.86$ & $8.92 \pm 2.09$ & $7.54 \pm 1.19$ & $25.70 \pm 2.90$ & $1.49 \pm 0.08$ & Sandy-clay-loam \\
\hline
\end{tabular}

Source: Authors (2020)

The predominance of sand indicates that soil has a low capacity for nutrient retention (ARAÚJO FILHO et al., 2017). In general, the soil density did not vary widely among the types of land use. For Marinho Junior et al. (2019), the removal of vegetation cover can cause physical changes in the soil, due to the impact of rain drops that fall directly on the exposed soil.

Soil microbiological indicators: carbon concentration in microbial biomass (C-MBC), basal soil respiration (BSR), microbial quotient (qMIC), metabolic quotient $\left(\mathrm{qCO}_{2}\right)$ and carbon stock in microbial biomass (S-MBC) showed significant differences in the different soil coverages analyzed. The interaction of litter and microorganisms has a fundamental role in the formation of the microbial metabolic activity of the soil, 
making the effect change of vegetation cover on the microbial activity more intense in the superficial layer of the soil than in greater depths (SOLEIMANI et al., 2019).

The C-MBC showed a variation of (161.58 to $463.49 \mathrm{mg} \mathrm{C} \mathrm{kg}^{-1}$ soil) in the $0-10$ $\mathrm{cm}$ layer and (94.99 to $461.50 \mathrm{mg} \mathrm{C} \mathrm{kg-1}^{-1}$ soil) in the layer $10-20 \mathrm{~cm}$ where, in general, there were no significant losses between the soil layers, except for the agricultural area (Figure 2).

Figure 2 - Carbon concentration in soil microbial biomass in different vegetation coverings in Cerrado, in Gurupi, Tocantins state, Brazil

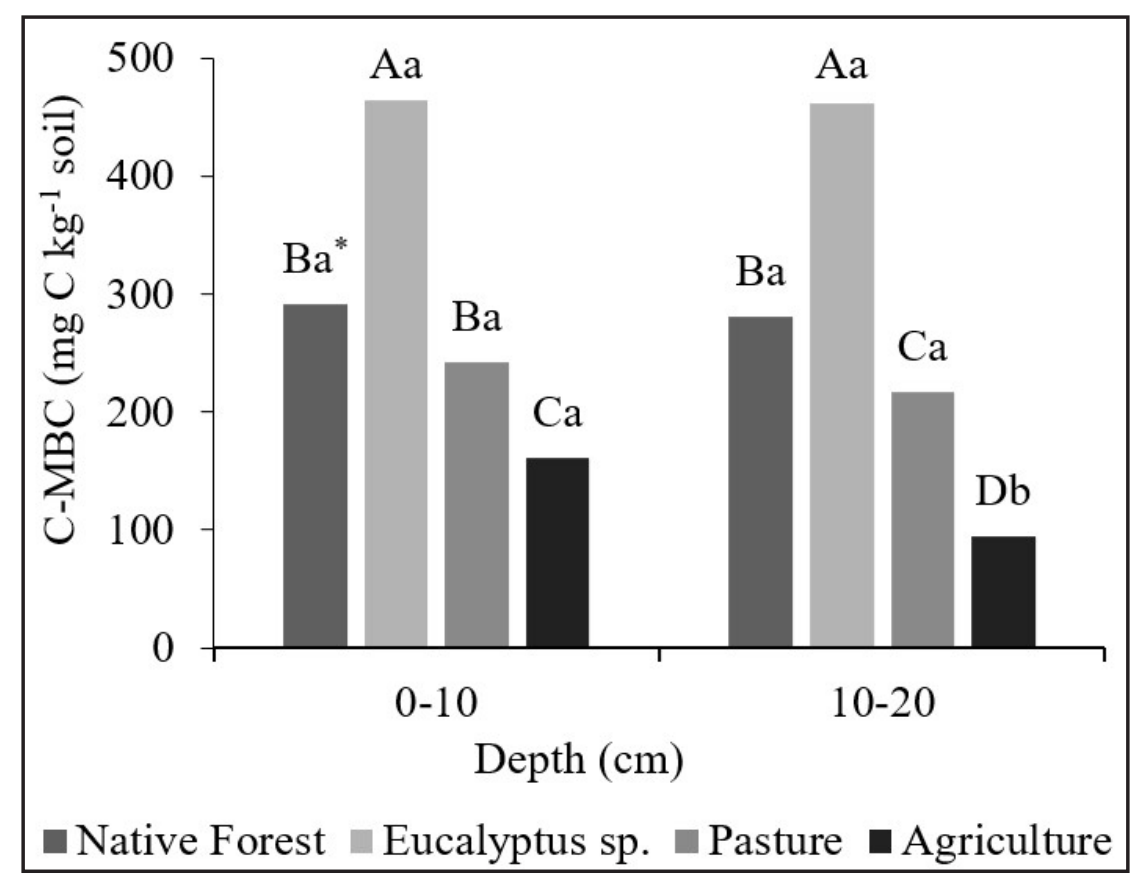

Source: Authors (2020)

In where: *Significant differences are indicated by different letters by the Tukey test at $5 \%$ significance level $(p \leq 0.05)$. Capital letters indicate differences between vegetation cover and lower letters indicate differences between soil layers.

Studies by Kaschuk, Alberton and Hungria (2010), evaluating the soil microbial biomass for three decades in Brazilian ecosystems, found values ranging from (46 to $1386 \mathrm{mg} \mathrm{C} \mathrm{kg}^{-1}$ soil) in different soil coverings in the Cerrado biome. Probably the low supply of organic matter in agriculture area has reduced the activity of soil 
microorganisms and consequently reduced the C-MBC in contrast to the greater availability of organic matter mainly via litter for native forest area and Eucalyptus sp. area, and via thin root system for pasture area has ensured a more stable microbial activity and possibly a higher MBC content.

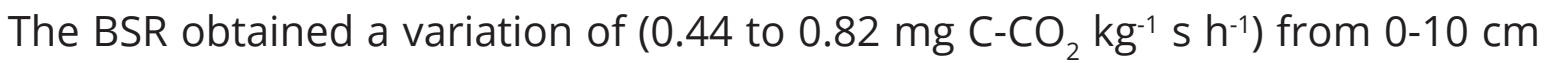

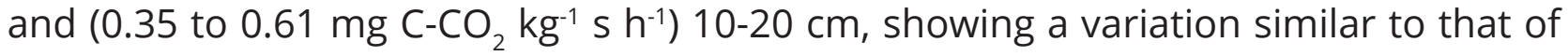
C-MBC among the evaluated areas and in the soil layers except for the agricultural area (Figure 3).

Figure 3 - Basal soil respiration in different vegetation coverings in Cerrado in Gurupi, Tocantins state, Brazil

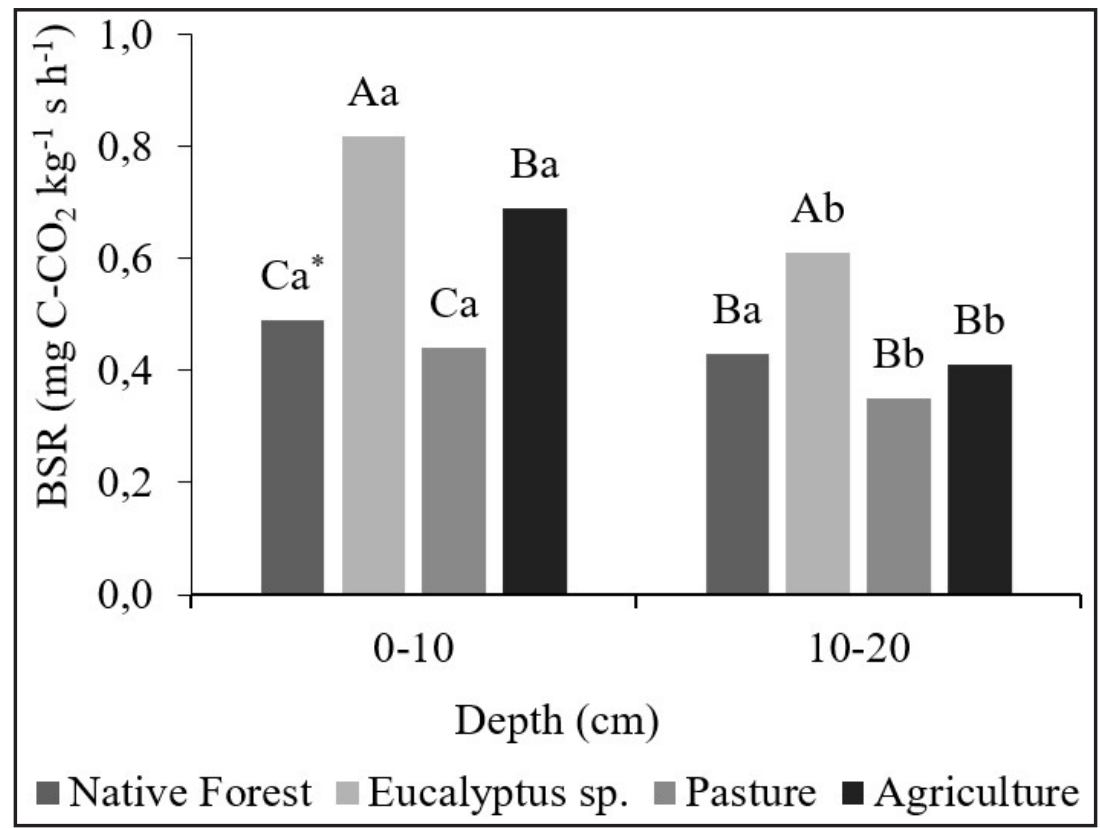

Source: Authors (2020)

In where: *Significant differences are indicated by different letters by the Tukey test at $5 \%$ significance level $(p \leq 0.05)$. Capital letters indicate differences between vegetation cover and lower letters indicate differences between soil layers.

According to Brito et al. (2019) attributes the variation in BSR to an ecological imbalance, as in his study evaluating BSR did not found no clear pattern in response to the change of the land use. According to Frazão et al. (2010), only BSR as soil microbial 
activity indicator can not explain its different behaviors among the evaluated areas. However, it is known that soil microbial activity is sensitive to substrate availability, humidity and temperature (ČAPEK et al., 2019). Studies by Oliveira et al. (2016), evaluating microbiological attributes in different uses of soil in Cerrado found great variation of BSR among the evaluated areas, being that the highest values were found in areas with greater presence organic matter (mainly labile), and warmer and dry periods.

The $\mathrm{qCO}_{2}$ and $\mathrm{qMIC}$ of soil are shown in Figure 4. The $\mathrm{qCO}_{2}$ evaluated soil showed

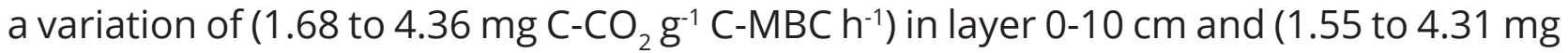
$\mathrm{C}-\mathrm{CO}_{2} \mathrm{~g}^{-1} \mathrm{C}-\mathrm{MBC} \mathrm{h}^{-1}$ ) in layer $10-20 \mathrm{~cm}$, without significant difference between native forest, Eucalyptus sp. and pasture areas, being the largest values found in agriculture area in both depths.

Figure 4 - Metabolic quotient and microbial quotient of soil in different vegetation coverings in Cerrado in Gurupi, Tocantins state, Brazil

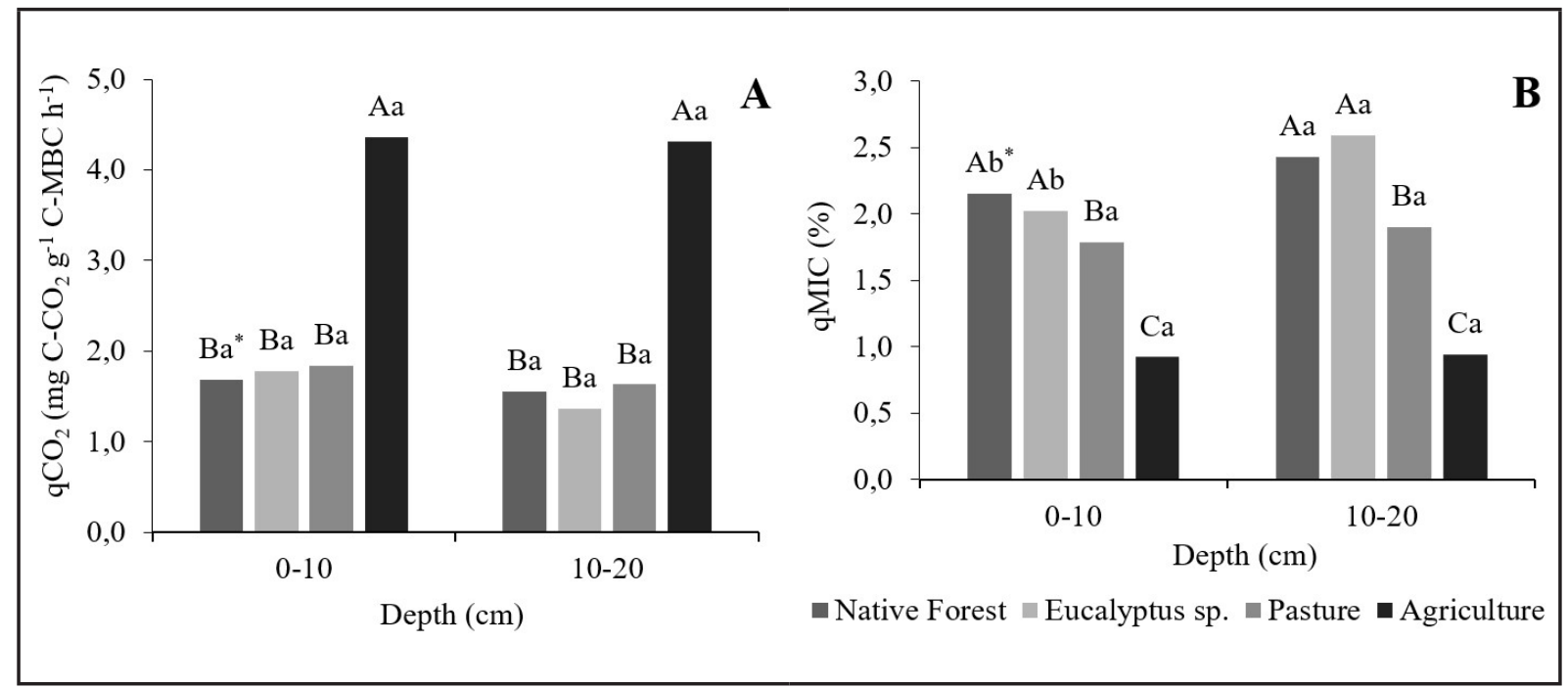

Source: Authors (2020)

In where: *Significant differences are indicated by different letters by the Tukey test at 5\% significance level $(p \leq 0.05)$. Capital letters indicate differences between vegetation cover and lower letters indicate differences between soil layers.

Higher $\mathrm{qCO}_{2}$ values indicate soils under stress or disturbance related to quality 
or quantity of the substrate and/or to unfavorable environmental conditions such as adverse microclimate or soil compaction (BRITO et al., 2019). The low $\mathrm{qCO}_{2}$ values are related to more stable areas with low degree of disturbance, indicating less loss of $C$ in $\mathrm{CO}_{2}$ form through respiration per unit of biomass (YAGHOUBI KHANGHAHI et al., 2019), according to the results found in an area with native forest, Eucalyptus sp. and pasture where there is less or no disturbance. The high $\mathrm{qCO}_{2}$ index is caused by higher metabolic activity per unit of biomass that stimulates the greater consumption of soil organic matter without its transformation into MBC and indicating less environmental sustainability (GRAZZIOTTI et al., 2017).

The qMIC showed a variation $0-10 \mathrm{~cm}(0.92$ to $2.15 \%)$ and $10-20 \mathrm{~cm}$ (0.94 to 2.59 \%) showing that there was significant difference between areas and layers evaluated (Figure 4B).

Lower values qMIC in agriculture area compared to the other areas indicate that there are lower proportions of labile organic matter and stable soil organic matter (MGANGA; RAZAVl; KUZYAKOV, 2016). qMIC values below 1.0 indicate a slower process for mineralization of OM in these systems (NUNES et al., 2018). Another interesting factor is that in $10-20 \mathrm{~cm}$ layer qMIC was superior in all evaluated areas, which may indicate a better quality of SOM, or even a better efficiency of microorganisms in the use of organic compounds in this depth soil. Nunes et al. (2018), evaluating microbiological attributes in different monocultures in the Cerrado of Piauí state, found a qMIC that varied from (1.06 to $2.66 \%$ ). Data that corroborate with presented in this study.

Carbon stock in microbial biomass (S-MBC) varied between $(0.21$ to $0.65 \mathrm{Mg}$ $\left.\mathrm{ha}^{-1}\right)$ in $0-10 \mathrm{~cm}$ and $\left(0.12\right.$ to $\left.0.64 \mathrm{Mg} \mathrm{ha}^{-1}\right)$ in $10-20 \mathrm{~cm}$, showing significant differences between the vegetation cover analyzed (Figure 5).

There is a maintenance S-MBC with an increase in depth, without significant differences in the soil layers evaluated, except in the agricultural area, which showed $42.86 \%$ reduction in S-MBC in 10-20 cm layer in relation to the surface layer 0-10 cm (Figure 5). Studies by Brito et al. (2019) evaluating S-MBC in response to land conversions 
in the Brazilian savannah, after changing the land use, found significant reductions in S-MBC, representing (-56\%) in conversion to pasture and $(-39 \%)$ in conversion to Eucalyptus plantation.

Figure 5 - Carbon stocks in microbial biomass in different vegetation coverings in Cerrado in Gurupi, Tocantins, Brazil

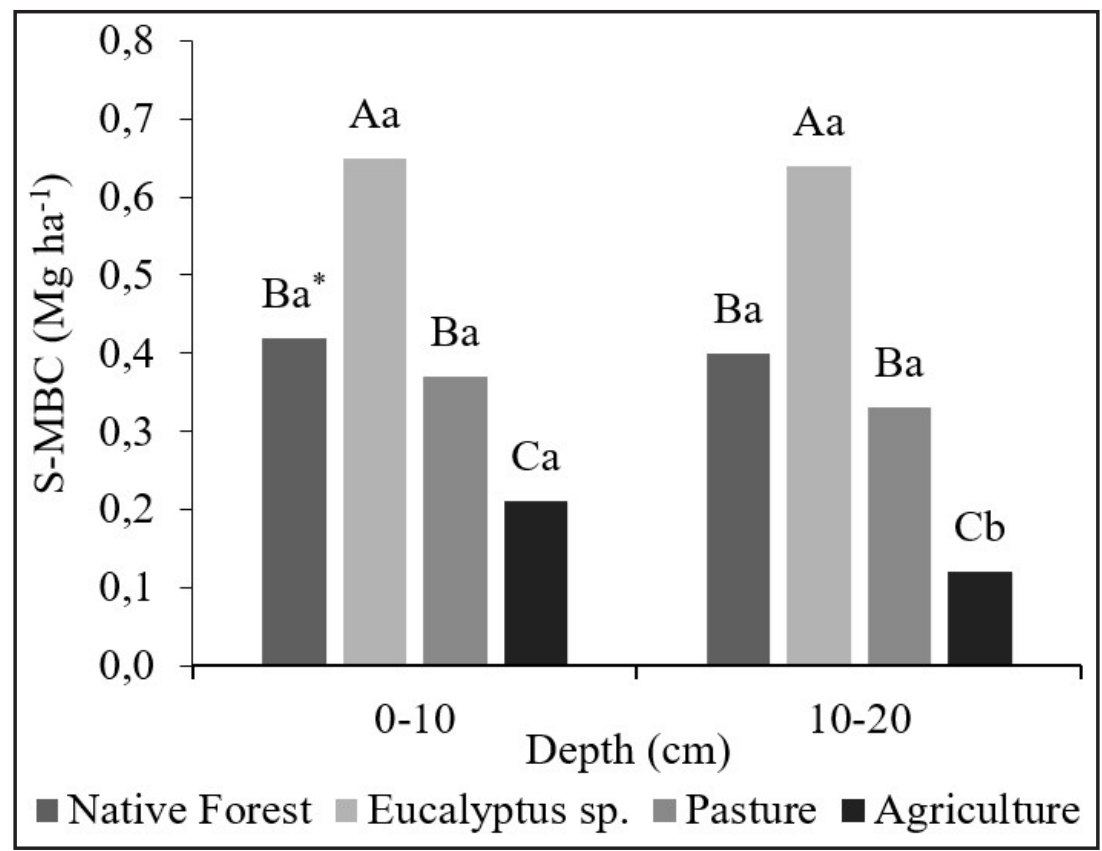

Source: Authors (2020)

In where: *Significant differences are indicated by different letters by the Tukey test at $5 \%$ significance level $(p \leq 0.05)$. Capital letters indicate differences between vegetation cover and lower letters indicate differences between soil layers.

The S-MBC low level can indicate low microbiological activity soil, and/or low disposition of organic material, generating low decomposition of the organic residues. The low values found in the MBC stocks for agricultural area can be attributed to little or no soil coverage at certain times of year, causing a reduction in the microbiological activity. For Rameshet al. (2019), this result can also be attributed to high C/N ratios found in agricultural systems that significantly reduce the MBC content and consequently reducing the mineralization process. On other hand, there was a superiority in MBC 
stocks in soil of Eucalyptus sp. not showing significant losses between the evaluated layers, which can be attributed to the great availability of organic matter in the form of litter.

The results found in soil microbial activity corroborate with S-MBC found, indicating great stability of evaluated area reflecting in a greater capacity to store carbon in soil. According to Soleimani et al. (2019), reforested areas are effective in increasing organic carbon content in soil and microbial biomass carbon compared to the natural forest.

The high BSR, C-MBC and S-MBC found in Eucalyptus sp. may represent a stable microbial activity justified by large amount of organic matter in this area. In the agricultural area, results were found contrasted with other areas in indicators of C-MBC, S-MBC, $\mathrm{qCO}_{2}$ and $\mathrm{qMIC}$, which may indicate a lower stability of the microbial activity in this soil, due to the low availability of organic matter in certain times of year. In the areas of pasture and native forest, which presented average results in most indicators and similar results to Eucalyptus sp. area in indicators such as $\mathrm{qCO}_{2}$ and qMIC, it can be attributed to greater stability in those areas that do not have recent anthropic interference, which ensure a large amount of organic matter in soil and consequently a stable microbial activity.

\section{CONCLUSIONS}

The vegetation area of Eucalyptus sp. showed minor changes in the microbiological activities.

C-MBC, BSR and S-MBC were significantly higher in Eucalyptus sp. area, and lower in agriculture, pasture and native forest area.

The activities mediated by microorganisms were affected by the change in the soil cover.

Microbiological activities proved efficient to be used in the control and analysis of degraded areas. 


\section{ACKNOWLEDGEMENTS}

The authors would like to thank CAPES for the grant of a master's scholarship, Universidade Federal de Pernambuco (UFRPE), Universidade Federal de Sergipe (UFS) and Universidade Federal de Pernambuco (UFPE), for their availability, facilities, cooperation and assistance.

\section{REFERENCES}

ANDERSON, T. H.; DOMSCH, K. H. Ratios of microbial biomass carbon to total organic carbon in arable soils. Soil Biology and Biochemistry, Oxford, v. 21, n. 4, p. 471-479, 1989. DOI: https:// doi.org/10.1016/0038-0717(89)90117-X

ARAÚJO FILHO, R. N. et al. Influência dos atributos físico-mecânicos do solo na estabilidade do talude do rio São Francisco. Revista Scientia Agraria, Curitiba, v. 18, n. 4, p. 107-113, 2017. DOI: http://dx.doi.org/10.5380/rsa.v18i4.52140

BARTLETT, R. J.; ROSS, D. S. Colorimetric determination of oxidizable carbon in acid soil solutions. Soil Science Society of America Journal, Madison, v. 52, n. 4, p. 1191-1192, jul. 1988. DOI: https://doi.org/10.2136/sssaj1988.03615995005200040055x

BATJES, N. H. Harmonized soil property values for broad-scale modelling (WISE30sec) with estimates of global soil carbon stocks. Geoderma, Amsterdam, v. 269, p. 61-68, may 2016. DOI: https://doi.org/10.1016/j.geoderma.2016.01.034

BENDITO, B. P. C. et al. Espécies do cerrado com potencial para recuperação de áreas degradadas, Gurupi (TO). Revista Agrogeoambiental, Pouso Alegre, v. 10, n. 2, jun. 2018. DOI: http://dx.doi.org/10.18406/2316-1817v10n220181117

BRITO, G. S. de et al. Labile soil organic carbon loss in response to land conversion in the Brazilian woodland savanna (cerradão). Biogeochemistry, Amsterdam, v. 144, n. 1, p. 31-46, may 2019. DOI: https://doi.org/10.1007/s10533-019-00570-9

ČAPEK, P. et al. Apparent temperature sensitivity of soil respiration can result from temperature driven changes in microbial biomass. Soil Biology and Biochemistry, Elmsford, v. 135, p. 286293, aug. 2019. DOI: https://doi.org/10.1016/J.SOILBIO.2019.05.016

DONAGEMMA, G. K. et al. Análise Granulométrica. In: TEIXEIRA, P. C. et al. (ed.). Manual de métodos de análise de solo. 3. ed. rev. e ampl. Brasília: Embrapa, 2017. 573 p.

FERREIRA, D. F. Sisvar: a computer statistical analysis system. Ciência e Agrotecnologia, Lavras, v. 35, n. 6, p. 1039-1042, nov./dez. 2011. DOI: https://doi.org/10.1590/S141370542011000600001 
FRAZÃO, L. A. et al. Inorganic nitrogen, microbial biomass and microbial activity of a sandy Brazilian Cerrado soil under different land uses. Agriculture, Ecosystems and Environment, Amsterdam, v. 135, n. 3, p. 161-167, jan. 2010. DOI: https://doi.org/10.1016/j.agee.2009.09.003

GRAZZIOTTI, D. et al. Microbiological Attributes of Soil Under Spontaneous Restoration. Floresta e Ambiente, Rio de Janeiro, v. 24, e20160069, apr. 2017. DOI: https://doi.org/10.1590/21798087.006916

ISERMEYER, H. Eine einfache Methode zur Bestimmung der Bodenatmung und Karbonate im Boden. Zeitschrift für Pflanzenernährung und Bodenkunde, Germany, v. 56, n. 1/3, p. 26$38,1952$.

ISLAM, K. R.; WEIL, R. R. Microwave irradiation of soil for routine measurement of microbial biomass carbon. Biology and Fertility of Soils, Heidelberg, v. 27, n. 4, p. 408-416, sep. 1998. DOI: https://doi.org/10.1007/s003740050451

KASCHUK, G.; ALBERTON, O.; HUNGRIA, M. Three decades of soil microbial biomass studies in Brazilian ecosystems: lessons learned about soil quality and indications for improving sustainability. Soil Biology and Biochemistry, Elmsford, v. 42, n. 1, p. 1-13, jan. 2010. DOI: https://doi.org/10.1016/j.soilbio.2009.08.020

MARINHO-JUNIOR, J. L. et al. Physical Attributes of Soil in Different Forest Cover in South of Tocantins. International Journal of Plant \& Soil Science, West Bengal, v. 31, n. 2, p. 1-7, dec. 2019. DOI: https://doi.org/10.9734/ijpss/2019/v31i230205

MGANGA, K. Z.; RAZAVI, B. S.; KUZYAKOV, Y. Land use affects soil biochemical properties in Mt. Kilimanjaro region. Catena, Germany, v. 141, p. 22-29, jun. 2016. DOI: https://doi.org/10.1016/j. catena.2016.02.013

MOGHIMIAN, N. et al. Evaluating soil biochemical/microbial indices as ecological indicators of different land use/cover in northern Iran. Acta Ecological Sinica, China, v. 39, n. 4, p. 328-333, aug. 2019. DOI: https://doi.org/10.1016/j.chnaes.2019.05.006

MOSCATELLI, M. C. et al. Microbial indicators related to soil carbon in Mediterranean land use systems. Soil and Tillage Research, Amsterdam, v. 97, n. 1, p. 51-59, nov. 2007. DOI: https:// doi.org/10.1016/j.still.2007.08.007

MUSHINSKI, R. M.; GENTRY, T. J.; BOUTTON, T. W. Forest organic matter removal leads to longterm reductions in bacterial and fungal abundance. Applied Soil Ecology, Amsterdam, v. 137, p. 106-110, may 2019. DOI: https://doi.org/10.1016/j.apsoil.2019.01.017

NUNES, L. A. P. L. et al. Microbiological attributes of yellow oxissol under different monocultures in the savana region of Piauí state. Bioscience Journal, Uberlândia, v. 34, n. 5, p. 1210-1218, oct. 2018. DOI: https://doi.org/10.14393/BJ-v34n5a2018-39463

OLIVEIRA, W. R. D. et al. Dynamics of soil microbiological attributes under integrated production systems, continuous pasture, and native cerrado. Pesquisa Agropecuária Brasileira, Brasília, v. 51, n. 9, p. 1501-1510, set. 2016. DOI: https://doi.org/10.1590/s0100-204×2016000900049

RAMESH, T. et al. Soil organic carbon dynamics: impact of land use changes and management practices: a review. Advances in Agronomy, San Diego, v. 156, p. 1-107, 2019. DOI: https://doi. org/10.1016/bs.agron.2019.02.001 
SANTOS, H. G. et al. Sistema Brasileiro de Classificação de Solos. 5. ed. Brasília: Embrapa, 2018. 588 p.

SOLEIMANI, A. et al. Influence of land use and land cover change on soil organic carbon and microbial activity in the forests of northern Iran. Catena, Germany, v. 177, p. 227-237, jun. 2019. DOI: https://doi.org/10.1016/j.catena.2019.02.018

TOCANTINS. Secretaria de Planejamento e Orçamento. Gerência de Indicadores Econômicos e Sociais. Projeto de Desenvolvimento Regional Integrado e Sustentável. Zoneamento Ecológico-Econômico do Estado do Tocantins. Diagnóstico Ecológico-Econômico do Estado do Tocantins. Palmas, 2018. v. 1-2.

YAGHOUBI KHANGHAHI, M. et al. Soil Biological Fertility and Bacterial Community Response to Land Use Intensity: A Case Study in the Mediterranean Area. Diversity, London, v. 11, n. 11, p. 211, nov. 2019. DOI: https://doi.org/10.3390/d11110211

\section{Authorship Contribution}

\section{1 - Josué Luiz Marinho Junior}

Civil Engineer, MSc.

https://orcid.org/0000-0001-9998-3550•josue.marinho@hotmail.com

Contribution: Conceptualization, Data curation, Formal Analysis, Investigation, Methodology

\section{2 - Victor Casimiro Piscoya}

Forestry Engineer, Dr., Professor

https://orcid.org/0000-0003-1875-9771 • victorcasimiropiscoya@gmail.com

Contribution: Software, Supervision, Writing - review \& editing

\section{3 - Moacyr Cunha Filho}

Civil Engineer, Dr., Professor

https://orcid.org/0000-0002-3466-8143•moacyr2006@gmail.com

Contribution: Formal Analysis, Investigation, Methodology

\section{4 - Milton Marques Fernandes}

Forestry Engineer, Dr., Professor

https://orcid.org/0000-0002-9394-0020•miltonmf@gmail.com

Contribution: Conceptualization, Data curation, Formal Analysis 


\section{5 - Alceu Pedrotti}

Agronomist, Dr., Professor

https://orcid.org/0000-0003-3086-8399 • alceupedrotti@gmail.com

Contribution: Writing - original draft, Writing - review \& editing

\section{6 - Thaisa Oliveira Folha Piscoya}

Chemical Engineer, MSc.

https://orcid.org/0000-0002-8419-1566•thaisafolha@gmail.com

Contribution: Software, Supervision, Validation, Visualization

\section{7 - Raimundo Rodrigues Gomes Filho}

Agronomist, Dr., Professor

https://orcid.org/0000-0001-5242-7581•rrgomesfilho@gmail.com

Contribution: Data curation, Formal Analysis, Investigation, Methodology

\section{8 - Fabricio Souza Campos}

Veterinary Doctor, Dr., Professor

https://orcid.org/0000-0002-5948-472X • camposvet@gmail.com

Contribution: Writing - original draft, Writing - review \& editing

\section{9 - Francisco Sandro Rodrigues Holanda}

Agronomist, Dr., Professor

https://orcid.org/0000-0001-6812-6679•fholanda@infonet.com.br

Contribution: Formal Analysis, Investigation, Methodology

\section{0 - Jamilie Brito de Castro}

Forestry Engineer

https://orcid.org/0000-0002-8179-9779• jamiliejbc@gmail.com

Contribution: Formal Analysis, Investigation, Methodology

\section{1 - Jorge Luis Piscoya Roncal}

Mechanical Engineer, MSc., Professor

https://orcid.org/0000-0001-8474-6771•jpiscoya@unitru.edu.pe

Contribution: Writing - original draft, Writing - review \& editing 


\section{2 - Renisson Neponuceno de Araújo Filho}

Forestry Engineer, Dr., Professor

https://orcid.org/0000-0002-9747-1276•nepoaraujo@gmail.com

Contribution: Project administration, Resources, Software, Supervision, Validation,

Visualization

\section{How to quote this article}

Marinho Junior, J. L.; Piscoya, V. C.; Cunha Filho, M.; Fernandes, M. M.; Pedrotti, A.; Pisco-ya, T. O. F.; Gomes Filho, R. R.; Campos, F. S.; Holanda, F. S. R.; Castro, J. B.; Roncal, J. L. P.; Araújo Filho, R. N. Soil microbiological activity under different vegetation coverages in the Cerrado biome of Tocantins state. Ciência Florestal, Santa Maria, v. 31, n. 3, p. 1494-1511, 2021. DOI 10.5902/1980509847922. Available from: https://doi.org/10.5902/1980509847922. Accessed: xx abbreviated-month. 2021. 